\title{
A different dihydropyridine calcium channel blocker in hypertensive patients who developed pedal edema on dihydropyridine calcium channel blocker therapy
}

\author{
Dihidropiridin grubu bir kalsiyum kanal blokeri tedavisi strasında ayak bileği \\ ödemi gelişen hipertansif hastalarda farklı bir dihidropiridin kalsiyum kanal \\ blokerinin kullanımı
}

\author{
Ayşe Yüksel, Ahmet Karagöz*, Özgül Uçar, Abdullah Çelik, Sinan Aydoğdu \\ Department of Cardiology (A. Yüksel, MD), Abdurrahman Yurtaslan Oncology Education and \\ Research Hospital, TR-06200 Ankara, Department of Cardiology (Assist Prof. A. Karagöz, MD), \\ Giresun University, 28200, Giresun, Cardiovascular Surgery Clinic, (A. Çelik, MD), Giresun \\ Professor Doctor Atilla İlhan Özdemir State Hospital, TR-28100 Giresun, Department of \\ Cardiology (Assoc. Prof. Ö. Uçar, MD), Ankara Numune Education and Research Hospital, TR- \\ 06230 Ankara, Department of Cardiology (Prof. S. Aydoğdu, MD), Yüksek İhtisas Education and \\ Research Hospital, TR-06100 Ankara
}

\begin{abstract}
Aim. Dihydropyridine calcium channel blockers (CCB) are widely preferred for the treatment of hypertension for their efficacy, metabolic neutrality and low side effect profile. However pedal edema formation limits their usage. The aim of the present study is to evaluate the incidence of pedal edema formation with a different dihydropyridine CCB in hypertensive patients who developed pedal edema during a dihydropyridine CCB therapy. Method. Fifty-eight hypertensive patients (34 female, 24 male, mean age: 65.3 \pm 10.5 ) in whom pedal edema developed during treatment with a dihydropyridine CCB (amlodipine $10 \mathrm{mg} /$ day in 40 patients, amlodipine $5 \mathrm{mg} /$ day in 14 patients, nifedipine GITS 30mg/day in 4 patients) were enrolled. CCB which caused pedal edema was withdrawn and a different CCB (felodipine or lacidipine) were initiated after the resolution of the pedal edema. CCB therapy was continued as long as the patient tolerated pedal edema. Results. At the end of one year, 44 out of 58 patients (36 [81.8\%] free of pedal edema, 8 [19.2\%] with pedal edema) continued CCB therapy. Eleven $(37.9 \%)$ patients in the felodipine group and $9(31.0 \%)$ patients in the lacidipine group developed pedal edema. In 7 patients in felodipine group and in 5 patients in the lacidipine group the study drug was withdrawn due to pedal edema. In two patients, study drug was withdrawn due to intractable headache (felodipine group) or due to flushing (lacidipine group). Conclusion. A different group of dihydropyridine $\mathrm{CCB}$ be used as an alternative therapy for hypertension whenever pedal edema develops during treatment with a dihydropyridine CCB.
\end{abstract}

Keywords: Hypertension, dihydropyridine calcium channel blockers, edema

\section{Özet}

Amaç. Dihidropiridin kalsiyum kanal blokerleri (KKB) etkinlikleri, metabolik nötraliteleri ve düşük yan etki profilleri nedeniyle hipertansiyon tedavisinde yaygın olarak tercih edilirler. Ancak tedavi sırasında ayak bileği ödemi gelişimi kullanımlarını kısıtlar. Bu çalışmanın amacı dihidropiridin KKB tedavisi sırasında ayak bileği ödemi gelişen hipertansif hastalarda farklı bir dihidropiridin KKB' ne geçilmesiyle ayak bileği ödemi gelişim oranının araştırılmasıdır. Yöntem. Dihidropiridin KKB tedavisi sırasında ayak bileği ödemi gelişen 58 hipertansif hasta (34 kadın, 24 erkek, ortalama yaş $65,3 \pm 10,5$ ) çalışmaya alındı. Bunlardan 40'ında ayak bileği ödemine yol açan KKB amlodipin 10mg/gün, 14'ünde amlodipin $5 \mathrm{mg} /$ gün ve 4'ünde nifedipine GITS 30mg/gün idi. Ayak bileği ödemi yapan KKB kesilerek ödem kaybolduktan sonra farklı bir dihidropiridin KKB (felodipin ya da lasidipin) başlandı. Yeni başlanan KKB tedavisine hasta ayak bileği ödemini tolere ettikçe devam edildi. Bulgular. Bir yıllık takip dönemi sonunda 58 hastadan $44(\% 75,9)$ tanesi (36 [\%81.8] ödemsiz, 8 [\% 18.2] ödemli olarak) KKB tedavisine devam ediyordu. Felodipin 
grubunda $11(\% 37,9)$ ve lasidipin grubunda $9(\% 31,0)$ hastada ayak bileği ödemi gelişti. Felodipin grubunda 7, lasidipin grubunda 5 hastada ayak bileği ödemi geliştiği için tedavi kesildi. Felodipin grubunda bir hastada şiddetli başağrısı, lasidipin grubunda bir hastada ise flushing nedeniyle tedavi sonlandırıldı. Sonuç. Dihidropiridin KKB tedavisi sırasında ayak bileği ödemi gelişen hipertansif hastalarda KKB tedavisini kesmek yerine başka gruptan bir dihidropiridin KKB alternatif olarak kullanılabilir.

Anahtar sözcükler: Hipertansiyon, dihidropiridin kalsiyum kanal blokerleri, ödem

Geliş tarihi/Received: April 11, 2013; Kabul tarihi/Accepted: February 13, 2014

\section{*Corresponding author:}

Dr. Ahmet Karagöz, Kardiyoloji Anabilim Dalı, Giresun Üniversitesi, TR-28200 Giresun. E-mail: drahmetkgz@hotmail.com

\section{Introduction}

Dihydropyridine calcium channel blockers (CCB) are widely preferred agents in the management of hypertension either alone or in combination with other drugs due to their high efficacy, metabolic neutrality and low side effect profile. Pedal edema is the most common adverse event with these drugs. This adverse effect is dose dependant with an incidence of $5 \%$ with $5 \mathrm{mg}$ and $25 \%$ with $10 \mathrm{mg}$ of amlodipine [1]. The drug is either withdrawn or the dose is reduced whenever disturbing pedal edema develops and this can result in impaired blood pressure control. Not all the members of this antihypertensive class share the same adverse event risk profile. In previous studies, newer generation, long-acting dihydropyridine CCBs are shown to have lower rates of pedal edema when compared to older ones [2, 3]. What about shifting to another dihydropyridine CCB when intolerant pedal edema develops? Only a few studies addressed this issue [4]. Therefore in our study we aimed to find out the incidence of pedal edema formation and the proportion of patients who maintain therapy after switching to a different dihydropyridine $\mathrm{CCB}$ in hypertensive patients who had already developed pedal edema on a dihydropyridine CCB therapy.

\section{Material and methods}

The study is a prospective, open-label, single-center study. The study was made in Numune Education and Research Hospital between April 2007 and May 2009. Written informed consent was obtained from all patients before randomization into the study. This study is approved by local Ethics Commitee of Numune Education and Research Hospital and is conducted in accordance with the Declaration of Helsinki. Fifty-eight hypertensive patients (34 female, 24 male, mean age: $65.3 \pm 10.5$ ) were enrolled in the study who experienced pedal edema during treatment with a dihydropyridine CCB. Exclusion criteria were secondary hypertension, chronic renal failure (serum creatinine higher than $2 \mathrm{mg} / \mathrm{dL}$ ), systolic heart failure, moderate to severe pulmonary hypertension and known venous insufficiency.

Dihydropyridine CCB which caused pedal edema was withdrawn and a different dihydropyridine CCB (felodipine or lacidipine) was initiated after resolution of the pedal edema. In patients who were on combination therapy, the anti-hypertensive drugs other than CCBs were continued. The second-line dihydropyridine CCB was chosen as felodipine or lacidipine, which were available newer generation dihydropyridine CCBs during the study period. The starting doses for felodipine and lacidipine were adjusted according to doses of former antihypertensive drugs and blood pressure measurements at baseline. Dose was titrated according to blood pressure measurements for each visit. A detailed physical examination and transthoracic echocardiography were performed and blood samples and 12-lead ECG were taken before randomization. Blood pressure was measured by a mercury sphygmomanometer with the patient in sitting position after at 
least 10 minutes of rest. The systolic and diastolic blood pressures were recorded at Korotkoff phases I and V, respectively. The average of three consecutive measurements were recorded. Follow-up visits were made at 2 weeks, 1 month, 6 months and 12 months after randomization. In each visit systolic and diastolic blood pressures, heart rate, pedal edema and other adverse events such as, dizziness, headache, flushing, palpitations were noted. The occurence of pedal edema was assessed subjectively (grading the pitting from 1 to 4) by a blinded physician who had to confirm the patient's report in terms of presence or absence of pedal edema. When the patient declared intolerant swelling or heaviness in the lower extremity, the drug was withdrawn.

\section{Statistical analysis}

Was performed using SPSS version 11.0 (SPSS Inc, Chicago, Illinois). Data were presented as mean $\pm \mathrm{SD}$ for continuous variables if they are distributed normally and differences between groups were assessed by unpaired samples T-test. Categorical variables were presented as percentages and were compared using Fisher exact test or Chi-square test. A p value $<0.05$ was accepted as significant.

\section{Results}

Fifty-eight hypertensive patients (34 female, 24 male, mean age: $65.3 \pm 10.5$ ) in whom pedal edema developed during treatment with a dihydropyridine CCB were enrolled in the study. The drug which caused pedal edema were; amlodipine $10 \mathrm{mg} /$ day in 40 patients, amlodipine 5mg/day in 14 patients and nifedipine GITS $30 \mathrm{mg}$ in 4 patients. The mean duration of hypertension was $10.1 \pm 7.8$ years and at baseline $24(41.4 \%)$ patients were on monotherapy with a $\mathrm{CCB}$ and $34(58.6 \%)$ patients were on a combination therapy including a CCB. The patients were using the CCB which caused pedal edema for an average of $19.8 \pm 25.8$ months. Pedal edema developed at $37.7 \pm 76.8$ weeks of treatment and disappeared in $6.2 \pm 4.8$ days after discontinuation of the causative CCB. Demographic and clinical characteristics of subjects are given in Table 1.

Table 1. Baseline demographic and clinical characteristics of subjects $(n=58)$.

\begin{tabular}{ll}
\hline Age (years) & $65.3 \pm 10.5$ (range: $37-78)$ \\
Sex (M/F) & $24(41.4 \%) / 34(58.6 \%)$ \\
Diabetes mellitus (n) & 11 \\
Rhythm (n) (sinus/atrial fibrillation) & $53 / 5$ \\
Baseline pulse rate (bpm) & $81 \pm 10.4$ (range: $67-110)$ \\
Duration of hypertension (years) & $10.1 \pm 7.8$ (range: $0.1-30)$ \\
Duration of CCB therapy (months) & $19.8 \pm 25.8$ (range: $0.5-84)$ \\
Time needed for development of pedal edema (weeks) & $37.7 \pm 76.8$ (range: $0.3-320)$ \\
Disappearance of pedal edema (days) & $6.2 \pm 4.8$ (range: $2-20)$ \\
\hline
\end{tabular}

CCB: Calcium channel blocker.

Second-line CCB was felodipine in 29 patients and lacidipine in 29 patients. Mean starting doses for felodipine and lacidipine were $6.2 \pm 0.6 \mathrm{mg} /$ day and $3.7 \pm 0.7 \mathrm{mg} /$ day, respectively. At the end of one year 44 out of 58 patients ( 36 free of pedal edema, 8 with pedal edema) continued CCB therapy. Eleven (37.9\%) patients in the felodipine group and $9(31.0 \%)$ patients in the lacidipine group developed pedal edema. In $7(24.1 \%)$ patients in felodipine group and in $5(17.2 \%)$ patients in lacidipine group the study drug was withdrawn due to pedal edema. Nevertheless it should be noted that the comparison of these two drugs with respect to pedal edema rates is beyond the scope of this study. Mean felodipine dose was $7.8 \pm 4.7 \mathrm{mg} /$ day and mean lacidipine dose was $4.9 \pm 1.6 \mathrm{mg} /$ day at 12 months. The mean age of the 20 patients who developed pedal edema was $68.4 \pm 6.9$ and the mean age of the 36 patients free of pedal edema after one year was $63.7 \pm 11.8$ $(\mathrm{p}=0.063)$ Table 2. Adverse effects other than pedal edema (dizziness, headache, flushing, palpitations) were rarely reported. In only two patients, study drug was withdrawn due to intractable headache (felodipine group) or due to flushing (lacidipine group). Mean 
systolic and diastolic blood pressure values were significantly lower than baseline (the time that the patient had presented to outpatient clinic with pedal edema and the secondline CCB was initiated) at the end of the study $(145.7 \pm 16.9 \mathrm{mmHg}$ vs $129.1 \pm 12.9 \mathrm{mmHg}$ and $87.9 \pm 8.8 \mathrm{mmHg}$ vs $81.8 \pm 7.2 \mathrm{mmHg}, \mathrm{p}<0.0001$ and $\mathrm{p}=0.0003$; respectively).

Table 2.Comparison of patients who developed pedal edema with patients who were free of pedal edema at the end of the study.

\begin{tabular}{llll}
\hline & $\begin{array}{l}\text { Pedal edema (+) } \\
\mathbf{n = 2 0}\end{array}$ & $\begin{array}{l}\text { Pedal edema (-) } \\
\mathbf{n = 3 6}\end{array}$ & $\mathbf{p}$ \\
\hline Age & $68.4 \pm 6.9$ & $63.7 \pm 11.8$ & 0.063 \\
\hline Sex (M/F) & $5 / 15$ & $18 / 18$ & 0.094 \\
\hline Duration of index CCB therapy (months) & $16.6 \pm 23.8$ & $21.2 \pm 26.9$ & 0.55 \\
\hline Duration of second-line CCB therapy (months) & $4.3 \pm 6.8$ & - & 0.187 \\
\hline $\begin{array}{l}\text { Time needed for development of pedal edema for the } \\
\text { index CCB (weeks) }\end{array}$ & $19.2 \pm 46.9$ & $47.4 \pm 87.6$ & \\
\hline $\begin{array}{l}\text { Time needed for development of pedal edema for the } \\
\text { second-line CCB (weeks) }\end{array}$ & $14.1 \pm 8.6$ & & 0.579 \\
\hline $\begin{array}{l}\text { Disappearance of pedal edema after cessation of } \\
\text { index CCB (days) }\end{array}$ & $6.8 \pm 6$ & $5.9 \pm 4.2$ & 0.117 \\
\hline $\begin{array}{lll}\text { Concomitant ACE-ARB therapy } \\
\text { CCB: Calcium channel blocker, ACE: Angiotensin converting enzyme, ARB: Angiotensin receptor blocker. }\end{array}$ \\
\hline
\end{tabular}

\section{Discussion}

Our study revealed that pedal edema is a frequent side effect of dihydropyridine CCB therapy and a different group of dihydropyridine $\mathrm{CCB}$ can be used as an alternative therapy for hypertension when pedal edema develops.

Pedal edema is one of the most important reasons for dose reduction or discontinuation of dihydropyridine CCBs. Moreover pedal edema may cause misdiagnosis of heart failure or venous insufficiency, leading to unnecessary diagnostic studies. The mechanism of edema is increased capillary pressure due to arteriolar vasodilation and fluid leakage into the interstitium [1]. Diuretics or salt restriction are ineffective in alleviating this adverse effect. Combination therapy with angiotensin converting enzyme inhibitors or angiotensin receptor blockers may provide benefit in this setting [5, 6]. Another alternative may be switching to a different and newer generation dihydropyridine CCB. In a single-center study ankle edema developed in $47 \%$ of patients taking amlodipine and $20 \%$ of patients taking lacidipine at 12 weeks [7]. In another study on 828 elderly patients followed up for 12 months, edema rates were significantly higher with amlodipine than lercanidipine and lacidipine, whereas anti-hypertensive efficacy of all drugs were similar [2]. On the other hand, Şahin $\mathrm{M}$ et al. [8] presented that the rate of intra-group drug change in CCB therapy was $20.9 \%$ and the reason for shifting to another CCB was adverse effects in $9.6 \%$ of the patients. If a patient develops pedal edema with one dihydropyridine $\mathrm{CCB}$, does it mean that he will have the same problem with all dihydropyridine CCB? A study other than ours, tried to answer this question. One hundred twenty-five hypertensive subjects who experienced an adverse effect with amlodipine, nifedipine GITS, felodipine and nitrendipine received lercanidipine in the Lercanidipine Challenge Trial [4]. Lercanidipine reduced the overall incidence of edema by $46 \%$ in this 8 -week, open-label study. In our study $62.1 \%$ of patients were free of pedal edema with study drugs after a longer follow-up period of one year.

Our study has important clinical implications that patients with hypertension usually need combination therapy in order to reach blood pressure targets [9] and in some patients dihydropyridine CCBs are the only choise for combination. The major drawback of this oftenly prescribed agents is peripheral edema. Physicians tend to give up dihydropyridine CCBs when they are faced by this unpleasant side effect. Considering the results of the present study, switching to another dihydropyridine CCB may be a solution for the physician in case of patient intolerance to existing dihydropyridine CCB develops. 
The pedal edema rates with felodipine and lacidipine are higher than expected in our study. This result can be explained by the special characteristic of the study population that it consists of hypertensive patients who already developed pedal edema with a dihydropyridine CCB agent, indicating susceptibility to this side effect. In addition there were predominantly female and aged patients in the study group, who might experience more side effects during a CCB therapy $[10,11]$. The study has limitations that the study group is small and pedal edema was evaluated by physical examination only. Assessment of leg weight changes by water displacement method could be a more objective technique to evaluate pedal edema [5]. However in clinical practice the perception of edema by the patient determines the continuation of the therapy similar to our study. In addition, a longer follow-up period is required considering the fact that pedal edema can develop many years after the initiation of the therapy. In conclusion, in patients who develop intolerant pedal edema during dihydropyridine CCB therapy, switching to a different drug in the same family seems an acceptable alternative to withdrawal of the dihydropyridine CCB therapy.

\section{References}

1. Messerli FH. Vasodilatory edema: A common side effect of antihypertensive therapy. Am J Hypertens 2001; 14: 978-9.

2. Leonetti G, Magnani B, Pessina AC, Rappelli A, Trimarco B, Zanchetti A; COHORT Study Group. Tolerability of long-term treatment with lercanidipine versus amlodipine and lacidipine in elderly hypertensives. Am J Hypertens 2002; 15: 932-40.

3. Makarounas-Kirchmann K, Glover-Koudounas S, Ferrari P. Results of a metaanalysis comparing the tolerability of lercanidipine and other dihydropyridine calcium channel blockers. Clin Ther 2009; 31: 1652-63.

4. Borghi C, Prandin MG, Dormi A, Ambrosioni E; Study Group of the Regional Unit of the Italian Society of Hypertension. Improved tolerability of the dihydropyridine calcium-channel antagonist lercanidipine: The Lercanidipine Challenge Trial. Blood Press Suppl 2003; 1: 14-21.

5. Weir MR, Rosenberger C, Fink JC. A pilot study to evaluate a water displacement technique to compare effects of diuretics and ACE inhibitors to alleviate lower extremity edema due to dihydropyridine calcium antagonists. Am J Hypertens 2001; 14: 963-8.

6. Weir MR, Ferdinand KC, Flack JM, Jamerson KA, Daley W, Zelenkofske S. A noninferiority comparison of valsartan/hydrochlorothiazide combination versus amlodipine in black hypertensives. Hypertension 2005; 46: 508-13.

7. Andresdottir MB, van Hamersvelt HW, van Helden MJ, van de Bosch WJ, Valk IM, Huysmans FT. Ankle edema formation during treatment with the calcium channel blockers lacidipine and amlodipine: A single-centre study. J Cardiovasc Pharmacol 2000; 35: S25-30.

8. Şahin M, Demir S, Aktürk S, Fedakar A, Alıcı G, Özkan B, Yazıcıŏlu MV, Cakalağaoğlu C, Yıldız M, Esen AM, Türkmen MM. Frequent change of intragroup drug effect on the blood pressure control and adaptation of therapy in hypertensive patients. Kosuyolu Kalp Derg 2013; 16: 7-12.

9. Mancia G, De Backer G, Dominiczak A, Cifkova R, Fagard R, Germano G, Grassi G, Heagerty AM, Kjeldsen SE, Laurent S, Narkiewicz K, Ruilope L, Rynkiewicz A, Schmieder RE, Struijker Boudier HA, Zanchetti A, Vahanian A, Camm J, De Caterina R, Dean V, Dickstein K, Filippatos G, Funck-Brentano C, Hellemans I, Kristensen SD, McGregor K, Sechtem U, Silber S, Tendera M, Widimsky P, Zamorano JL, Kjeldsen SE, Erdine S, Narkiewicz K, Kiowski W, Agabiti-Rosei E, Ambrosioni E, Cifkova R, Dominiczak A, Fagard R, Heagerty AM, Laurent S, Lindholm LH, Mancia G, Manolis A, Nilsson PM, Redon J, Schmieder RE, Struijker-Boudier HA, Viigimaa M, Filippatos G, Adamopoulos S, Agabiti-Rosei E, Ambrosioni E, Bertomeu V, Clement D, Erdine S, Farsang C, 
Gaita D, Kiowski W, Lip G, Mallion JM, Manolis AJ, Nilsson PM, O'Brien E, Ponikowski P, Redon J, Ruschitzka F, Tamargo J, van Zwieten P, Viigimaa M, Waeber B, Williams B, Zamorano JL, The task force for the management of arterial hypertension of the European Society of Hypertension, The task force for the management of arterial hypertension of the European Society of Cardiology. 2007 Guidelines for the management of arterial hypertension: The Task Force for the Management of Arterial Hypertension of the European Society of Hypertension (ESH) and of the European Society of Cardiology (ESC). Eur Heart J 2007; 28: 1462-536.

10. Cherubini A, Fabris F, Ferrari E, Cucinotta D, Antonelli Incalzi R, Senin U. Comparative effects of lercanidipine, lacidipine, and nifedipine gastrointestinal therapeutic system on blood pressure and heart rate in elderly hypertensive patients: The ELderly and LErcanidipine (ELLE) study. Arch Gerontol Geriatr 2003; 37: 203-12.

11. Barbagallo M, Barbagallo Sangiorgi G. Efficacy and tolerability of lercanidipine in monotherapy in elderly patients with isolated systolic hypertension. Aging (Milano) 2000; 12: 375-9. 